\title{
A regulação \\ da contratação pública pelas agências reguladoras: limites e possibilidades
}

\author{
Rogério Gesta Leal ${ }^{1}$ \\ JANRIÉ RodRIGUES RECK ${ }^{2}$
}

\section{RESUMO}

O processo de contratação pública no Brasil está condicionada a um regime jurídico de direito público, que tem fundamento na Constituição Federal e o seu regramento infraconstitucional compreendido em parte nas leis infraconstitucionais e, em parte, na regulação operada pelas agências reguladoras no âmbito de suas respectivas atribuições. O objetivo deste artigo é identificar os limites e as possibilidades que as agências reguladoras brasileiras têm no âmbito da regulação da contratação pública e, para tanto, pergunta-se: quais são os limites e as possibilidades que as agências reguladoras brasileiras têm, no âmbito de suas atribuições, em matéria de regulação de contratação pública?

1 Desembargador do Tribunal de Justiça do Estado do Rio Grande do Sul, Porto Alegre, Brasil. Titular da Quarta Câmara Criminal, que julga crimes praticados por Prefeitos e Vereadores e Crimes contra a Administração Pública. Doutor em Direito pela Universidade Federal de Santa Catarina, UFSC, Florianópolis, Brasil. Professor Titular da Universidade de Santa Cruz do Sul, Santa Cruz do Sul, Brasil. Correo-e: gestaleal@gmail.com

2 Professor de Direito Administrativo do Curso de Direito da Universidade de Santa Cruz do Sul-unisC, Santa Cruz do Sul, Brasil. Doutorado em Direito na Universidade de Santa Cruz do Sul/RS, Santa Cruz do Sul, Brasil. Correo-e: janriereck@ibest.com.br. Fecha de recepción: 27 de septiembre de 2017. Fecha de modificación: 20 de octubre de 2017. Fecha de aceptación: 30 de octubre de 2017. Para citar el artículo: GeSTA Leal, Rocério, RODRIGUES RECK, JANRIÉ "A regulação pública pelas agências reguladoras: limites e possibilidades", Revista digital de Derecho Administrativo, Universidad Externado de Colombia, n. ${ }^{\circ}$ 19, 2018, pp. 49-81. DOI: https://doi.org/10.18601/21452946.n19.05 
Embora o tema não tem sido tratado pontualmente pela doutrina, nem pela jurisprudência das Cortes superiores, conclui-se que as agências reguladoras no Brasil podem exercer a regulação sobre a contratação pública, porque exercem parcela da atividade de regulação.

Palavras-Chave: Contratação pública, Regime jurídico, Agencias reguladoras, Constituição federal.

\title{
La regulación de la contratación pública por las agencias reguladoras: límites y posibilidades
}

\section{RESUMEN}

Los procesos de contratación pública en Brasil están condicionados por un régimen jurídico de derecho público, que encuentra sus bases en la Constitución federal, en normas de rango legal y en las regulaciones que expiden las autoridades administrativas reguladoras en el ámbito de sus respectivas competencias. El objeto de este artículo es identificar el alcance que las potestades normativas de las autoridades de regulación brasileras tienen en materia de contratos públicos.

Palabras clave: Contratación pública, Régimen jurídico, Agencias reguladoras, Constitución federal.

\section{The Scope of the Regulation of Public Procurement by Regulatory Agencies}

\begin{abstract}
Public procurement procedures in Brazil are subject to a public law regime, which finds its grounds in the Federal Constitution, in legal statutes and in the rules issued by administrative agencies in exercise of their regulatory powers. This paper intends to identify the reach of the rulemaking authority of Brazilian regulatory agencies in the field of public procurement.
\end{abstract}

Keywords: Public Procurement, Legal Regime, Regulatory Agencies, Federal Constitution. 


\section{INTRODUÇÃO}

O Estado contemporâneo ocidental que tem a sua gênese no Estado Liberal, construído a partir das ideias de Thomas Hobbes, John Locke e Jean-Jacques Rousseau, passou por metamorfoses, predominante por força de eventos econômicos e sociais, alcançando o que hoje se denomina Estado Democrático de Direito. Contudo, esse modelo de Estado vem se transformando, de um lado, porque a globalização econômica e as tecnologias de informação descontruíram o Estado-nação e, por outro, o Estado Democrático de Direito que tem a responsabilidade pela concretização dos direitos fundamentais, exigindo eficácia e eficiência na satisfação do interesse público, que em parte é materializado por meio da contratação pública.

A contratação pública no Brasil está condicionada a um regime jurídico de direito público, que tem fundamento na Constituição Federal e o seu regramento infraconstitucional compreendido em parte nas leis infraconstitucionais e, em parte, na regulação operada pelas agências reguladoras no âmbito de suas respectivas atribuições. A contratação pública se apresenta como um processo que, em síntese, pode-se dizer que tem início nas leis orçamentárias e finda com a entrega do objeto contratado e o pagamento integral pelo Estado contratante, sem afastar eventuais responsabilidades de natureza contratual que podem surgir após o seu termo final.

O objetivo geral deste artigo é identificar os limites e as possibilidades que as agências reguladoras brasileiras têm no âmbito de suas atribuições na regulação da contratação pública, como uma forma de contribuir para a discussão de um tema que tem sido pouco abordado a despeito da importância que possui e, para tanto, pergunta-se: quais são os limites e as possibilidades que as agências reguladoras brasileiras têm, no âmbito de suas atribuições, em matéria de regulação de contratação pública? E para o desenvolvimento da investigação, tratar-se-á inicialmente das transformações do Estado contemporâneo, em especial o Estado Regulador ${ }^{3}$, a regulação na perspectiva do Estado Democrático de Direito, das competências constitucionais em matéria de contratação pública e da regulação da contratação pública pelas agências reguladoras.

3 São características do Estado Regulador: "transferência para a iniciativa privada de atividades desenvolvidas pelo Estado, desde que dotadas de forte cunho de racionalidade econômica, liberalização de atividades até então monopolizadas pelo Estado a fim de propiciar a disputa pelos particulares em regime de mercado; a presença do Estado no domínio econômico privilegia a competência regulatória; a atuação regulatória do Estado se norteia não apenas para atenuar ou eliminar os defeitos do mercado, mas também para realizar certos valores de natureza política ou social ${ }_{i}$ e institucionalização de mecanismos de disciplina permanente das atividades reguladas". MarÇaL Justen FiLHo, Curso de Direito Administrativo, 4. ${ }^{a}$ ed. rev. atual., São Paulo: Saraiva, 2009, pp. 565-566. 


\section{DAS TRANSFORMAÇÕES DO ESTADO \\ CONTEMPORÂNEO E A CONTRATAÇÃO PÚBLICA NA PERSPECTIVA DO ESTADO REGULADOR}

Desde o final do Absolutismo, que caracterizou a Idade Média na Europa, com a instauração do Estado Liberal, fundado nos ideais da liberdade, igualdade e fraternidade, a despeito de ter implantado na prática apenas a liberdade formal, até os dias de hoje, o Estado de Direito passou por mutações importantes que contribuíram para um modelo de Estado, denominado como Estado Regulador. De acordo com Paulo Bonavides ${ }^{4}$, desde o século XVIII até o século XX, "o mundo atravessou duas grandes revoluções - a da liberdade e a da igualdade - segui das de mais duas", a da fraternidade que teve como objeto o homem concreto na sua ambiência planetária, ecológica e universal e a do Estado Social, cujo objetivo é a concretização dos direitos fundamentais.

O Estado Liberal institucionalizou-se no fim do século XVIII, fruto das Revoluções liberais, especialmente a Americana e a Francesa, constituindo o primeiro Estado de Direito, pondo fim ao regime imposto pelas monarquias absolutas, marcando a entrada na era da modernidade, que se caracteriza pela conjunção de elementos técnicos, econômicos e políticos, que traduzem na organização racional das sociedades ${ }^{5}$, a despeito da primeira expressão do Estado Moderno estar alicerçada na ideia de soberania que originou as primeiras monarquias absolutistas ${ }^{6}$. O Estado Liberal se caracterizou pelo primado da liberdade e, por decorrência abster-se de intervir na liberdade de contratar, na propriedade privada e na economia, assegurar o princípio da igualdade formal, a estruturação e a organização do Estado com base na Teoria da Separação de Poderes de Montesquieu, como uma técnica de limitação do poder governamental e a garantia dos direitos fundamentais de primeira dimensão.

A forte desigualdade promovida pelo Estado Liberal, ao se preocupar com a liberdade real e a igualdade apenas formal, fez com que surgissem transformações que modificaram o papel do Estado que deixou de ser mero observador, para se tornar ator e intervir no exercício das liberdades com a finalidade de substituir a igualdade formal pela real, portanto, uma concepção de Estado instrumental, comprometido com o bem estar de todos. Paulo Bonavides ${ }^{7}$ diferencia o Estado social de figurino autoritário - quer de extrema esquerda, quer

4 Paulo Bonavides, Do Estado Liberal ao Estado Social, 10. ${ }^{a}$ ed., São Paulo: Malheiros, 2001, p. 30 .

5 Jacques Chevallier, O Estado Pós-Moderno. Tradução de Marçal Justen Filho. Belo Horizonte: Fórum, 2009, p. 14.

6 Lenio Luiz Streck e José Luis Bolzan De Morais, Ciência política e teoria do estado, 7. a ed. Porto Alegre: Livraria do Advogado, 2012, p. 45.

7 Ibidem, p. 33 
de extrema direita - do Estado social da Sociedade, que é o Estado social dos direitos fundamentais, onde o Estado avulta menos e a sociedade avulta mais.

Este Estado é o Democrático de Direito, que mantém com a sociedade uma relação de cooperação mútua na formulação e execução das políticas públicas; tem um viés garantista, regido por regras e princípios, tendo como fim a assegurar os direitos fundamentais de primeira dimensão e a concretização dos direitos fundamentais de segunda e terceira dimensões e, além disso, guarda relação com o modelo de administração pública gerencial em substituição ao modelo burocrático, típico do Estado Liberal e Social.

Contudo, o Estado brasileiro, a despeito das obrigações impostas constitucionalmente, não conseguiu garantir a concretização dos direitos fundamentais de segunda e terceira dimensões, sob a justificativa da crise fiscal do Estado, que permeou os anos 80, e, além disso, a globalização da economia e financeira que impactaram fortemente as relações entre o público e o privado, contribuíram para uma nova formatação do Estado e, por consequência, da Administração Pública. Por um lado, a crise fiscal implicou a necessidade de reformar e reconstruir o Estado e, de outro, "a globalização tornou imperativa a tarefa de redefinir suas funções" ${ }^{11}$. A partir deste cenário o Estado brasileiro, como de resto os demais Estados periféricos econômico e socialmente, perderam a capacidade de prestar os serviços públicos diretamente, por falta de recursos financeiros e, além disso, foram forçados a deixar de atuar como empresários, em razão do mercado competitivo internacional.

É neste contexto que surge o Estado Regulador ${ }^{9}$, quando a intervenção direta na prestação de serviços públicos e nas atividades econômicas de produção e comercialização de bens é substituída por uma atuação indireta, nomeadamente por meio da regulação dos serviços públicos concedidos e permitidos com a finalidade de concretizar o princípio da eficiência, previsto no artigo 37 da Constituição Brasileira, assim, também, a regulação da economia por meio de regras e princípios com o propósito direcionar os seus rumos, crian-

8 Luiz Carlos Bresser Pereira, "Da administração pública burocrática à gerencial". In: Reforma do estado e administração pública gerencial, (Organizadores) Luiz Carlos Bresser Pereira e Peter

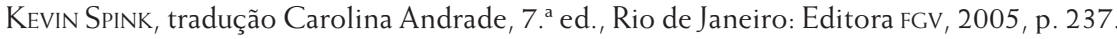

9 Como diferencial dos dois modelos ideais de Estado liberal e de Estado social, encontra-se o chamado Estado regulador, que se define pela proeminência não da interferência direta para promoção do desenvolvimento econômico social, nem mesmo da não-intervenção para dinamização do mercado, mas pelo papel de coordenação, de gerenciamento, de controle, de intervenção indireta, ou sinteticamente, de regulação estatal, entendendo-se esta última como resultado da compreensão do Estado e do mercado não mais como entes estanques ou antípodas, mas como fenômenos interdependentes e essenciais à consolida ção dos direitos fundamentais. Assim, a regulação não é, em si mesma, uma característica diferencial do modelo atual de Estado regulador, pois a presença de competências regulatórias no Estado brasileiro não é recente. Marcio Aranha, Manual de Direito Regulatorio (Locais do Kindle 1613-1617), Laccademia Publishing, Edição do Kindle. 
do mecanismos facilitadores para que a "economia nacional se torne internacionalmente competitiva" ${ }^{\prime 10}$, contribuindo para a concretização dos valores socialmente relevantes.

O Estado Regulador tem como característica a regulação que não se confunde com regulamentação, ainda que, de forma bastante ampla contribua para complementar a regulamentação, o que ocorre por meio do chamado direito regulatório. Desde o Estado Liberal cabe ao "direito público a função de disciplinar a estrutura de poder e expressar a dimensão jurídica de influência sobre esferas jurídicas alheias"11. Se considerarmos que a regulação tem por objeto atividades relevantes ao interesse público, o que não quer dizer exclusivamente atividades públicas, porque atividades privadas de interesse público, como por exemplo a produção de alimentos e medicamentos, estão sujeitas a regulação pela Agência Nacional de Vigilância Sanitária-ANVISA, então o direito regulatório é um ramo do direito público ${ }^{12}$.

No bojo das transformações pelas quais o modelo de Estado moderno vem passando e "abrange os sistemas econômicos apoiados sobre aquele modelo de Estado, o direito formal e os próprios mercados"113 altera-se o quadro institucional clássico, em que o princípio da legalidade, sacramentado na ideia de que a Administração Pública deve estar submetida à lei em sentido formal, portanto, oriunda do Poder Legislativo, e, por consequência, a atuação da Administração Pública direta e indireta era predominantemente executória, abrindo espaço para um pluralismo normativo, que transcende a lei e o seu regulamento editado pelo Poder Executivo, adicionando a função de regulação executada por agências reguladoras, que no Brasil são autarquias independentes, cuja finalidade, em sentido amplo, é a regulação estatal da economia ${ }^{14}$, alcançando os serviços públicos que tiveram sua execução concedida, permitida ou autorizada e atividades privadas de interesse público.

Nesta conjuntura as relações entre a esfera pública e a esfera privada sofreram profundas alterações, se comparadas com o estágio anterior, em especial

10 Ibidem, p. 236.

11 Marcio Aranha, Manual de Direito Regulatório (Locais do Kindle 329-334), Laccademia Publishing, Edição do Kindle.

12 Ibidem (Locais do Kindle 329-334).

13 Eros Roberto Grau, O direito posto e o direito pressuposto, 9. a edição revista e ampliada, São Paulo: Malheiros, 2014, p. 128.

14 "Preferimos adotar um conceito amplo de regulação estatal da economia, excluindo tanto a sua assimilação à desregulação, como apenaws à regulação coercitiva. Assim, podemos afirmar que a regulação estatal da economia deve, no atual momento histórico, sem perder de vista os valores humanos e sociais do Estado democrático, ser eficiente, adotando novas técnicas regulatórias - flexíveis e consensuais -, que, sem excluir as anteriores, a elas se somem poara serem mais eficazes e menos onerosas (para a sociedade e para o próprio Estado)". Alexandre Santos DE Aragão, Agências reguladoras: e a evolução do direito administrativo econômico, 3. ${ }^{a}$ edição revista e ampliada, Rio de Janeiro: Forense, 2013, pp. 31-32. 
o Estado Liberal e o Estado Social de natureza autoritária, em que a separação entre o público e o privado era mais nítida e o modelo da Administração Pública era o burocrático. A questão principal, contudo, não é a mera substituição de um modelo de administração por outro, mas a legitimidade e a efetividade da atuação da Administração Pública nas perspectivas administrativa e democrática, porquanto a institucionalização de novos mecanismos instrumentais, como é o caso das agências reguladoras, precisam agir em sintonia com os princípios e objetivos fundamentais, principalmente os previstos nos artigos $1{ }^{\circ}{ }^{\circ 15]}, 3 .^{\circ[16]}, 5 .^{\circ[17]}$ e $6 .^{\circ[18]}$, de acordo com Leal ${ }^{19}$, na perspectiva democrática e de concretização dos direitos fundamentais.

Enquanto os teóricos do Estado Administrativo adotam uma visão unilateral e reducionista em que a legitimidade está assentada na figura do administrador, o Estado Regulador seria o responsável pelo reposicionamento da questão da legitimidade democrática ao reconhecer no regulado um partícipe necessário da decisão política, relacionando-o, inclusive, às tradições de participação política da virtude política e do republicanismo, ao despersonalizar o administrador como detentor único de legitimidade, visto que os pressupostos do Estado Regulador "gravitam entre as percepções da regulação [...], passando pela concepção restritiva do administrador como síntese de legitimidade e de poderes estatais distribuídos entre a administração das leis e o poder de

15 "Art. 1. A República Federativa do Brasil, formada pela união indissolúvel dos Estados e Municípios e do Distrito Federal, constitui-se em Estado Democrático de Direito e tem como fundamentos: I - a soberania ${ }_{i}$ II - a cidadania ${ }_{i}$ III - a dignidade da pessoa humana IV - os valores sociais do trabalho e da livre iniciativa ${ }_{i}$ - o pluralismo político. Parágrafo único. Todo o poder emana do povo, que o exerce por meio de representantes eleitos ou diretamente, nos termos desta Constituição".

16 "Art. 3. ${ }^{\circ}$ Constituem objetivos fundamentais da República Federativa do Brasil: I - construir uma sociedade livre, justa e solidária; II - garantir o desenvolvimento nacional, III - erradicar a pobreza e a marginalização e reduzir as desigualdades sociais e regionais; iV - promover o bem de todos, sem preconceitos de origem, raça, sexo, cor, idade e quaisquer outras formas de discriminação".

17 "Art. 5. ${ }^{\circ}$ Todos são iguais perante a lei, sem distinção de qualquer natureza, garantindo-se aos brasileiros e aos estrangeiros residentes no País a inviolabilidade do direito à vida, à liberdade, à igualdade, à segurança e à propriedade, nos termos seguintes: $[\ldots]^{\prime \prime}$.

18 "Art. 6. ${ }^{\circ}$ São direitos sociais a educação, a saúde, a alimentação, o trabalho, a moradia, o transporte, o lazer, a segurança, a previdência social, a proteção à maternidade e à infância, a assistência aos desamparados, na forma desta Constituição".

19 "Tal perspectiva condiciona a legitimidade da Administração Pública no Estado Democrático de Direito, à existência de um processo democrático de comunicação política, que instituiu um espaço permanente de construção de entendimentos racionais sobre o que se pretende em termos de sociedade e governo, a partir da organização de mecanismos e instrumentos de cogestão que garantam a visibilidade, compreensão e debate das questões comunitárias relevantes (inclusive na definição de quais sejam), para em seguida, se passar ao nível do seus dimensionamentos em políticas públicas efetivadoras de demandas que elas apresentam". ROGÉRIO GESTA LEAL, Estado, administração pública e sociedade: novos paradigmas. Porto Alegre: Livraria do Advogado, 2006, p. 40. 
veto político ${ }^{\prime 20}$ e assim a regulação pode ser vista como um espaço público ou como institucionalização de virtude política e republicanismo ${ }^{21}$. Todavia, a mera existência de agências reguladoras é insuficiente para garantir o aperfeiçoamento democrático, tendo em vista que a virtude e do republicanismo não são inerentes a elas, mas podem servir de instrumento para suprir déficit democrático externo ${ }^{22}$.

As políticas públicas têm a sua legitimidade condicionada ao devido processo democrático, em que Estado e cidadão, envolvidos numa prática de entendimento/consenso, constroem pactos, que a despeito de provisórios, estão informados por princípios e valores universais, como os direitos fundamentais, emancipação dos povos, o controle do poder político e o desenvolvimento sustentável, entre outros ${ }^{23}$. Por esta razão, a atuação dos mecanismos de regulação não pode ficar à margem dos princípios, valores e objetivos definidos pela Constituição como reitores da organização política, jurídica e social do Estado brasileiro. Em outras palavras, a regulação dos contratos da Administração Pública no Brasil, tem a sua legitimidade condicionada à vinculação aos princípios, valores e objetivos, considerando a centralidade da Constituição e a vinculação de todos os atos do Estado à Constituição.

A contratação pública na perspectiva do Estado regulador, não pode ser observada à margem da noção de que o Estado é um instrumento de organização da sociedade, ao passo que o bem-estar é o objeto do Estado e que a tecnicização, diferenciação e autonomização dos vários subsistemas sociais repercutiram na organização das esferas decisórias estatais ${ }^{24}$ e assim a contratação pública está condicionada por leis formais oriundas do Poder Legislativo, por decretos regulamentadores editados pelos chefes dos Poderes Executivos, no âmbito de suas respectivas competências administrativas e, também, pela regulação executada por agências reguladoras, com a finalidade de restringir ou induzir comportamentos necessários para a concretização dos interesses sociais definidos pela Constituição e socialmente desejáveis, em atenção aos princípios, objetivos e direitos fundamentais.

20 Marcio Aranha, Manual de Direito Regulatório (Locais do Kindle 621-624), Laccademia Publishing, Edição do Kindle.

21 Ibidem (Locais do Kindle 621-624).

22 MarÇal Justen FilHo, "Agências reguladoras e democracia: existe um déficit democrático na "regulação independente?". In: O poder normativo das agências reguladoras, AlEXANDRE SANTOS de Aracão (Coordenador) ... [et al]. Rio de Janeiro: Forense, 2006, p. 314.

23 Rogério GeSTA LEAL, Estado, administração pública e sociedade: novos paradigmas. Porto Alegre: Livraria do Advogado, 2006, p. 39.

24 AleXANDRe Santos De AragÃo, Agências reguladoras: e a evolução do direito administrativo econômico, 3. ${ }^{a}$ edição revista e ampliada, Rio de Janeiro: Forense, 2013, p. 206. 


\section{DA REGULAÇÃO NA PERSPECTIVA DO ESTADO DEMOCRÁTICO DE DIREITO}

Na década de 1980 quando da passagem do regime autoritário para o democrático foi promulgada a Constituição de 1988, que deu ênfase à cidadania traduzida no garantismo dos direitos fundamentais e no princípio democrático, influenciada fortemente pelas Constituições Portuguesa de 1976 e Espanhola de 1978. Para a concretização dos direitos fundamentais a Constituição, originariamente, apresentava duas diretrizes acerca das atividades econômicas de prestação de serviços e de produção e comercialização de bens que norteavam a ação do Estado brasileiro, baseada numa ideia de um rígido controle do desenvolvimento econômico do Estado.

Acerca das atividades econômica de prestação, sintetizada nos serviços públicos, "de oferecimento de utilidade ou comodidade material, destinada à satisfação da coletividade em geral, mas fruível singularmente pelos administrados ${ }^{\prime \prime 25}$ alguns deveriam ser prestados diretamente ou mediante concessão a empresas sob controle acionário estatal, em especial os serviços telefônicos, telegráficos, de transmissão de dados e demais serviços públicos de telecomunicações, assegurada a prestação de serviços de informações por entidades de direito privado através da rede pública de telecomunicações explorada pela União ${ }^{26}$ e outros, como os os serviços e instalações de energia elétrica e o aproveitamento energético dos cursos de água, em articulação com os Estados onde se situam os potenciais hidroenergéticos podiam ser explorados diretamente pela União ou mediante autorização, concessão ou permissão ${ }^{27}$, cujo monopólio de empresas vinculadas ao poder estadual, obedeciam diretrizes fixadas pela Telebrás - Telecomunicações Brasileiras, autarquia federal, vinculada ao Ministério das Telecomunicações.

Em relação às atividades de produção e comercialização de bens, a Constituição estabeleceu, desde sua origem, que a exploração direta de atividade econômica pelo Estado só será permitida quando necessária aos imperativos da segurança nacional ou a relevante interesse coletivo, conforme definidos em lei, ressalvados os casos previstos pela próprio Constituição $\mathrm{o}^{28} \mathrm{e}$, quando o Estado brasileiro fosse atuar como empresário deveria fazê-lo por meio de empresa pública ou sociedade de economia mista ${ }^{29}$, cujo regime jurídico foi aprovado recentemente por força da Lei Federal n. ${ }^{\circ} 13.303$, de 30 de junho de 2016, o que não impediu que empresas estatais atuantes no mercado industrializando 
e comercializando bens, tivessem o seu controle acionario repassado à iniciativa privada.

Contudo, a própria Constituição Federal sinalizava com a noção de Estado regulador ao estabelecer que uma de suas funções seria a de agor como agente normativo e regulador da atividade econômica, o Estado exercerá, na forma da lei, as funções de fiscalização, incentivo e planejamento, sendo este determinante para o setor público e indicativo para o setor privado e, além disso, que que lei estabelecerá as diretrizes e bases do planejamento do desenvolvimento nacional equilibrado, o qual incorporará e compatibilizará os planos nacionais e regionais de desenvolvimento ${ }^{30}$.

Em face da crise fiscal e da globalização econômica, a partir dos anos de 1990 o Brasil passa a adotar uma política de desestatização da economia com a privatização de diversas empresas estatais que atuavam diretamente na economia, cujos fundamentos teóricos e práticos encontram-se nos processos de privatização que tomaram conta do cenário europeu da década de 1990 e na política de desregulação da economia nos Estados Unidos ${ }^{31}$, como por exemplo, as estatais siderúrgicas que começara a ser privatizadas com o desmonte da holdig Siderbrás, destacando-se a privatização da Usiminas em 1991 e a da Companhia Siderúrgica Nacional-CSN em 1993. Todo este processo de desestatização tem um marco inicial que é o Programa Nacional de Desestatização-PND, implantado pela Lei Federal n. ${ }^{\circ} 8.031^{[32]}$, de 12 de abril de 1990, a qual se constituiu em peça fundamental para a redefinição da atuação do Estado brasileiro ${ }^{33}$.

30 Artigo 174, § 1. ${ }^{\circ}$ da Constituição Federal.

31 Paulo Todescan Lessa Mattos, "Regulação econômica e democracia: contexto e perspectivas na compreensão das agências de regulação no Brasil". In: Regulação, Direito e Democracia, (Organizador) José Eduardo Faria, São Paulo: Editora Fundação Perseu Abramo, 2002, p. 55 .

32 Brasil, Lei n. ${ }^{\circ} 8.031$, de 12 de abril de 1990. Cria o Programa Nacional de Desestatização, e dá outras providências. Diário Oficial [da] República Federativa do Brasil, DF, Brasília, Seção I, página 7103, 13 de abril de 1990.

33 "No processo de redefinição das funções do Estado, o Governo distingue as atividades exclusivas do Estado, dos serviços sociais e científicos e da produção de bens e serviços para o mercado. Dentre as atividades exclusivas do Estado estão destacadas as funções de legislar, regular, julgar, policiar, fiscalizar, definir políticas e fomentar. Os serviços sociais e científicos serão financiados pelo Estado e prestados por organizações não-estatais. $\mathrm{O}$ Ministério da Administração e Reforma do Estado, nas palavras de Bresser Pereira, entende que essas atividades têm um caráter competitivo e não se enquadram nas funções que envolvem o poder de Estado, dessa forma podem ser financiadas pelo Estado mas gerenciadas pela iniciativa privada, disputando clientela, numa condição de 'quasemercado'". ILSE GOMES SiLVA, A reforma do Estado A reforma do Estado brasileiro nos anos 90: brasileiro nos anos 90: processos e contradições. Dispinível em: http://www4.pucsp.br/neils/downloads/ v7_ilse_gomes.pdf [Acesso em 26 de julho de 2017]. 
Alguns marcos importantes na reforma do Estado brasileiro decorrem da alteração da Constituição Federal: a Emenda Constitucional de n. ${ }^{0}{ }^{[34]}$, de 15 de agosto de 1995, retirou o monopólio do serviço de gás canalizado somente para empresa estatal, passado permitir que os Estados passassem a explorar diretamente, ou mediante concessão, os serviços locais de gás canalizado, na forma da lei, vedada, entretanto, a edição de medida provisória para a sua regulamentação; a Emenda Constitucional de n. ${ }^{\circ} 8^{[35]}$, de 15 de agosto de 1995, extinguiu o monopólio das telecomunicações, permitindo que a União passasse a explorar, diretamente ou mediante autorização, concessão ou permissão, os serviços de telecomunicações, nos termos da lei, que disporá sobre a organização dos serviços, a criação de um órgão regulador e outros aspectos institucionais; assim como explorar, diretamente ou mediante autorização, concessão ou permissão os serviços de radiodifusão sonora e de sons e imagens.

A Emenda Constitucional de n. ${ }^{\circ}{ }^{[36]}$, de 9 de novembro de 1995, quebrou o monopólio do petróleo, ao alterar o parágrafo primeiro do artigo 177, estabelecendo que a União poderá contratar com empresas estatais ou privadas a realização das atividades a pesquisa e a lavra das jazidas de petróleo e gás natural e outros hidrocarbonetos fluidos; a refinação do petróleo nacional ou estrangeiro; a importação e exportação dos produtos e derivados básicos resultantes das atividades previstas nos incisos anteriores; o transporte marítimo do petróleo bruto de origem nacional ou de derivados básicos de petróleo produzidos no País, bem assim o transporte, por meio de conduto, de petróleo bruto, seus derivados e gás natural de qualquer origem, observadas as condições estabelecidas em lei.

Outra Emenda Constitucional, considerada a derradeira em termos de reforma do Estado brasileiro, foi a de.$^{\circ}{ }^{1} 9^{[37]}$, de 4 de junho de 1998 , que alterou os incisos XIV e XXII do art. 21 e XXVII do art. 22 da Constituição Federal, que afetaram sensivelmente a Administração Pública brasileira, alterando

34 Brasil, Emenda Constitucional de n. ${ }^{\circ}$ 5, de 15 de agosto de 1995 - Altera o $§ 2 .^{\circ}$ do art. 25 da Constituição Federal. Disponível em: http://www.planalto.gov.br/ccivil_03/constituicao/emendas/emc/emc05.htm [Acesso em 26 de julho de 2017].

35 Brasil, Emenda Constitucional de n. ${ }^{\circ}$ 8, de 15 de agosto de 1995 - Altera o inciso XI e a alínea "a" do inciso XII do art. 21 da Constituição Federal. Disponível em: http://www. planalto.gov.br/ccivil_03/constituicao/emendas/emc/emc08.htm [Acesso em 26 de julho de 2017].

36 Brasil, Emenda Constitucional de n. ${ }^{\circ}$ 9, de 9 de novembro de 1995 - Dá nova redação ao art. 177 da Constituição Federal, alterando e inserindo parágrafos. Disponível em: http:// www.planalto.gov.br/ccivil_03/constituicao/Emendas/Emc/emc09.htm\#art3 [Acesso em 26 de julho de 2017].

37 Brasil, Emenda Constitucional de n. ${ }^{\circ} 19$ de 9 de novembro de 1995 - Modifica o regime e dispõe sobre princípios e normas da Administração Pública, servidores e agentes políticos, controle de despesas e finanças públicas e custeio de atividades a cargo do Distrito Federal, e dá outras providências. Disponível em: http://www.planalto.gov.br/ccivil_03/ constituicao/emendas/emc/emc19.htm [Acesso em 26 de julho de 2017]. 
o regime e dispondo sobre princípios e normas da Administração Pública, servidores e agentes políticos, controle de despesas e finanças públicas e custeio de atividades a cargo do Distrito Federal a tal ponte de ser chamada de reforma administrativa.

Também no plano infraconstitucional é possível destacar a Lei federal de n. ${ }^{\circ} 8.987$, de 13 de fevereiro de 1995, que disciplina, de uma forma geral, o regime de concessão e permissão da prestação dos serviços públicos, definindo que é considerado o poder concedente, o que é concessão de serviço público, concessão de serviço público precedida da execução de obra pública e permissão de serviço público e, também, que serviço público adequado é o que satisfaz as condições de regularidade, continuidade, eficiência, segurança, atualidade, generalidade, cortesia na sua prestação e modicidade das tarifas, sobre os direitos e obrigações dos usuários, sobre a política tarifária, a licitação para a concessão e a permissão dos serviços públicos, dos contratos de concessão e permissão, dos encargos do poder concedente, da concessionária e da intervenção, entro outras disposições.

Destaca-se, também, duas leis federais que organizam serviços públicas de telecomunicações e energia elétrica e instituem as respectivas agências reguladoras. A primeira é a Lei Federal de n. ${ }^{\circ}$ 9.472, de 16 de julho de 1997, que dispõe sobre a organização dos serviços de telecomunicações, a criação e funcionamento de órgão regulador, que é a Agência Nacional de Telecomunicações-ANATEL, e outros aspectos institucionais de acordo com as alterações introduzidas pela Emenda Constitucional de n. ${ }^{\circ} 8$, anteriormente referida, permitido a transferência desta espécie de serviço público em favor de empresas ou consórcios de empresas privadas e a segunda é a Lei federal n. ${ }^{\circ}$ 9.427, de 26 de dezembro de 1996, que institui a Agência Nacional de Energia Elétrica - ANEEL, disciplina o regime das concessões de serviços públicos de energia elétrica entre outras providências.

O repasse da execução dos serviços públicos em favor da iniciativa privada, a indução à publicização por meio do chamado terceiro setor ou setor público não-estatal e a privatização de empresas estatais de natureza mercantil não afastaram a intervenção do Estado, apenas mudou a forma, que passou a ser por meio da regulação, portanto, uma mudança de paradigma, deixando ser um Estado prestador de serviços e produtor de bens, para exercer predominantemente as funções de regulação, fiscalização e planejamento das atividades econômicas, setorizando-as, por meio da criação de agências reguladoras.

Estas transformações apresentaram e apresentam desafios importantes, porque de um lado, o conceito de regulação estatal se transmuta em razão da mudança que se estabeleceu no relacionamento entre Estado e Sociedade, em face da ampliação dos campos de atuação de regulação estatal e, também, pela introdução de instrumentos de atuação estatal sobre as relações econômicas e o fortalecimento do direito da concorrência, substituindo a atuação direta e indireta do Estado no domínio econômico, para atuar sobre o domínio 
econômica por meio de instrumentos e finalidades diferentes. Por outro lado, no bojo destas reformas, a noção de serviço público também sofreu alterações, por força do processo de privatização de empresas estatais, quebrando o monopólio da exploração destas atividades, impactando não somente as formas de exploração, mas os próprios instrumentos teóricos explicativos da noção de serviço público ${ }^{38}$.

Todo este contexto de reforma do Estado, com a introdução de novos instrumentos, importados de outros contextos jurídicos, econômicos e sociais, trouxe indagações de várias ordens e um dos pontos tormentosos relacionados à regulação é o seu déficit democrático ${ }^{39}$, que precisa ser superado para que esteja em sintonia com o ideário do Estado Democrático de Direito, porquanto a democracia é um de seus pressupostos. Este déficit seria causado por duas razões, uma geral decorrente da administrativização do Direito Público e outras específicas, derivadas da estabilidade temporária dos dirigentes das agências reguladoras que não podem ser exonerados ad nutum pelos agentes legitimados democraticamente, mesmo contrariando a vontade do agente político e o seu programa de governo sufragado democraticamente ${ }^{40}$. No Brasil, instaurou-se controvérsia acerca da constitucionalidade das agências reguladoras à luz do sistema democrático configurado na Constituição de 1988, tendo como base a discussão sobre o déficit democrático na indicação dos membros do Parlamento Europeu e a solução passou a aludir-se a legitimação pelo procedimento, fundado não na vinculação à vontade popular, mas no modo pelo qual exercitariam seus poderes ${ }^{41}$.

Ampliando um pouco mais, para combater e superar a ideia de déficit democrático, legisladores, intérpretes e a construção doutrinária e jurisprudencial

38 Floriano Peixoto De Azevedo Marques Neto, "Nova regulação dos serviços públicos", Revista de Direito Administrativo, Rio de Janeiro, v. 228, pp. 13-30, abr. 2002. ISSN 2238-5177. Disponível em: http://bibliotecadigital.fgv.br/ojs/index.php/rda/article/view/46521 [Acesso em: 27 Jul. 2017]. DOI: http://dx.doi.org/10.12660/rda.v228.2002.46521.

39 O termo foi cunhado por David Marquand, em 1979, ao apontar a deficiência na forma de indicação dos membros do Parlamento europeu, que eram indicados indiretamente pelos parlamentos nacionais. A despeito de a questão europeia ter sido superada com a eleição dos membros do Parlamento europeu, a expressão sobreviveu e ganhou generalizações, indicando "não apenas a ausência de mecanismos de participação direta do cidadão na formação da vontade política, mas também a inaplicação das concepções clássicas de tripartição dos poderes à organização comunitária europeia. MARÇAL JuSTEN FILHO, "Agências reguladoras e democracia: existe um déficit democrático na "regulação independente?", In: O poder normativo das agências reguladoras, AleXandre Santos de Aracão (Coordenador) ... [et al], Rio de Janeiro: Forense, 2006, p. 302.

40 AleXandre Santos De AraGÃo, Agências reguladoras: e a evolução do direito administrativo econômico, 3. ${ }^{a}$ edição revista e ampliada, Rio de Janeiro: Forense, 2013, pp. 465-466.

41 MarÇal Justen FilHo, "Agências reguladoras e democracia: existe um déficit democrático na "regulação independente?", In: O poder normativo das agências reguladoras, AleXANDRE SANTOS DE Aragão (Coordenador) ... [et al], Rio de Janeiro: Forense, 2006, p. 303. 
construíram mecanismos e paradigmas legitimadores das agências reguladoras independentes, destacando-se: a) que as agências reguladoras ao serem criadas por lei - artigo 37, XIX, da Constituição Federal -, por iniciativa do Chefe do Poder Executivo - artigo 61, § 1' ${ }^{\circ}$ II 'e', da Constituição Federal -, são legitimadas por titulares de dois poderes legitimados democrático-eleitoralmente; b) ao ponderar os interesses envolvidos as agências reguladoras devem procurar realizar a maior efetividade possível, alcançando, sempre que possível, o consenso ${ }_{i}$ c) um dos mecanismos da legitimação da Administração Pública é a participação dos titulares e defensores dos interesses individuais, coletivos e difusos no processo de tomada das decisões que lhes afetarão; e, d) as agências reguladoras exercem poderes neutrais do Estado, infensos ao menos imediatamente às mudanças político-eleitorais, assegurando o pluralismo no seio do Estado sem retirar totalmente os poderes do Chefe do Poder executivo e do Poder Legislativo ${ }^{42}$.

A despeito da impossibilidade de uma definição padronizada de democracia, é possível afirmar que certas funções sejam ocupadas por sujeitos escolhidos pela vontade popular, que as decisões concretas estejam em sintonia com os princípios, objetivos e direitos fundamentais, sem prejuízo dos valores que orientam os meios a serem utilizados e os fins a serem atingidos por meio da função pública, assim como proteger os interesses das minorias e que os valores fundamentais sejam realizados e assegurados mesmo contra a vontade majoritária ou de extratos significativos da população e a participação popular na formação da vontade política, embora nem todas as decisões são produzidas pela vontade do povo ${ }^{43}$.

Portanto, a despeito de a democracia informar a organização estatal, nem todos os órgãos ou entidades precisam ser dirigidas por agentes eleitos pelo povo. Devem ser eleitos os ocupantes dos cargos estruturais dos órgãos legiferantes e governativos. Os primeiros atuarão como representantes do povo para a tomada de decisões no âmbito da competência legislativa, sem afastar a participação popular, quando a Constituição Federal prevê e os últimos eleitos para fazer a gestão do interesse público. Contudo, é "indispensável a existência de organismos administrativos a funcionar como freios e contrapesos como a ampliar o processo de comunicação entre a Sociedade e a burocracia" ${ }^{\prime \prime 4}$. E neste sentido o autor conclui que a agência reguladora reflete uma dupla proposta de aperfeiçoamento do sistema democrático. Por um lado, nem todas as decisões estatais podem ser alicerçadas exclusivamente no critério da vontade popular,

42 AleXandre Santos de Aragão, Agências reguladoras: e a evolução do direito administrativo econômico, 3. ${ }^{a}$ edição revista e ampliada, Rio de Janeiro: Forense, 2013, pp. 466 e seguintes.

43 MaRÇAL JUSTEN FILHO, "Agências reguladoras e democracia: existe um déficit democrático na "regulação independente?", In: O poder normativo das agências reguladoras, ALEXANDRE SANTOS DE ARAGÃo (Coordenador) ... [et al], Rio de Janeiro: Forense, 2006, p. 305.

Ibidem, p. 313. 
por outro, é necessário ampliar os canais de comunicação entre o Estado e a Sociedade, por meio da participação popular e dos grupos organizados para a formação de decisões relevantes para os setores envolvidos ${ }^{45}$.

É certo que as agências reguladoras, entidades autarquias, são criadas por lei específica, em atenção ao comando constitucional previsto no artigo 37, XIX, o que permite afirmar que as agências reguladoras possuem legitimidade derivada, por força de lei anterior que lhe outorga o poder normativo. E, neste sentido, a justificativa constitucional sobre o poder normativo delas decorre de duas teorias: a sujeição especial e a da deslegalização. A primeira afirma que a edição de atos normativos pelas agências decorre do poder especial que as agências detêm para exercer a regulação em face de determinados interesses e, a segunda, afirma que o ato de regulação é legítimo porque o próprio legislador retirou do domínio da lei em favor da regulação exercida pela agência reguladora. O Supremo Tribunal Federal-stF na Adin-MC n. ${ }^{\circ}$ 1.668-DF, se posicionou pela constitucionalidade do poder normativa das agências reguladoras, ao assegurar as funções normativas, desde que subordinadas à legislação ${ }^{46}$.

Embora a legitimidade democrática das agências reguladoras esteja sendo reconhecida por importante parcela da doutrina administrativista brasileira, é certo também, que as agências reguladoras, enquanto autoridades administrativas independentes, agravam o déficit pelo fato de que "os fundamentos de suas atividades costumam ser dotadas de elevado grau de vagueza, generalidade e abstração, que transferem aos administradores inúmeras decisões de cunho político ${ }^{\prime 47}$, abrindo espaço para o perigo da imposição tecnocrática em detrimento da democrática, ou seja, a o fortalecimento da decisão técnica e a negação da decisão política.

Outra questão importante relacionada com a legitimidade democrática das agências reguladoras, é a que envolve os interesses que estão em jogo no momento da decisão: o interesse do próprio Estado, o interesse das empresas

46 Brasil, Supremo Tribunal Federal. Pleno. ADin-MC n 1.668-DF. Relator: Ministro Marco Aurélio. Brasília, julgado em 20 de agosto de 1998. Publicado no Diário da Justiça em 31 de agosto de 1998. Para ilustrar, segue um trecho do voto do Ministro Sepúlveda Pertence: "nada impede que a Agência tenha funções normativas, desde, porém, que absolutamente subordinadas à legislação, e, eventualmente, às normas de segundo grau, de caráter regulamentar, que o Presidente da República entenda baixar. Assim, [... entendo que nada pode subtrair da responsabilidade do agente político, que é o Chefe do Poder Executivo, a ampla competência reguladora da lei das telecomunicações. Dou interpretação conforme para enfatizar que os incisos IV e X referem-se a normas subordinadas à lei e, se for o caso, aos regulamentos do Poder Executivo".

47 Gustavo Binenbojm, "Agências reguladoras independentes e Democracia no Brasil", In: Agências Reguladoras e Democracia, Gustavo Binenbojm (Coordenador), Rio de Janeiro: Lúmen Juris, 2006, p. 104. 
concessionárias e o interesse dos usuários. Como fica a legitimidade democrática diante da participação dos representantes dos usuários, leigos nos assuntos técnicos postos na pauta decisória da agência? ${ }^{48}$ Estas são algumas, dentre outras indagações, que mantém em aberto a questão da legitimidade democrática das agências reguladoras.

Além disso desenvolve-se no Brasil um permanente processo de captura político-partidário das agências reguladoras, onde por um lado elas servem para satisfazer interesses fisiológicos de partidos políticos e, de outro, como moeda de troca para aprovação de projetos de interesse do Governo e, neste sentido, falseando a legitimidade democrática, por meio do que há de mais nefasto para a democracia, que é a corrupção. De acordo com o Ministro Luiz Roberto Barroso, do Supremo Tribunal Federal-STF, está ocorrendo uma deformação nas agências reguladoras, por força do loteamento partidário dos órgãos reguladores, carcterizada pela "captura das agências pelo processo político, com elas deixando de ter sua neutralidade e passando a ser cobiçadas pelas múltiplas legendas partidárias que poluem a paisagem política brasileira" ${ }^{\prime 4}$.

Contudo, a regulação sobre as atividades econômicas de prestação de serviços e de produção de bens e serviços é uma realidade e, neste contexto, a contratação pela Administração Pública de bens, obras e serviços entre outros, sofre os efeitos da regulação. Por isso, na sequência far-se-ão algumas considerações acerca das competências constitucionais sobre a matéria envolvendo contratação pública, para ao final poder apresentar resposta a indagação formulada sobre os limites e as possibilidades da regulação em matéria de contratação pública.

\section{DAS COMPETÊNCIAS CONSTITUCIONAIS EM MATÉRIA DE CONTRATAÇÃO PÚBLICA NO BRASIL}

A primeira observação que se faz necessária, ao tratar das competências constitucionais em termos de contratação pública, é esclarecer que o conceito de contratação pública vai além dos contratos em sentido estrito, alcançando todo e qualquer ajuste entre órgãos ou entidades da Administração Pública e particulares, em que haja um acordo de vontades para a formação de vínculo e a estipulação de obrigações recíprocas, seja qual for a denominação utilizada. Além disso, contratação é um processo que tem o seu ponto de partida nas leis orçamentárias e chega a termo quando da entrega do bem contratado, o

48 Conrado Hübner Mendes, "Reforma do Estado e Agências Reguladoras: estabelecendo parâmetros para discussão", in: Direito Administrativo Econômico, Carlos Ari SundFeld (Coordenador), São Paulo: Malheiros, 2000, p. 131.

49 Disponível em: http://exame.abril.com.br/economia/agencias-reguladoras-perderam-seu-papel-diz-barroso/ [Acesso em: 25 de julho de 2017]. 
que denota a multiplicidade de competêncais que estão em jogo sempre que a Administração Pública participa de uma contratação pública.

Por esta razão, não se fará aqui uma análise exaustiva sobre as competências constitucionais sobre a contratação, mas apenas referências às principais competências que demarcam o tema, partindo do pressuposto de que em parte, as políticas públicas no Brasil, depois de formuladas se concretizam, senão na totalidade, ao menos parcialmente, por meio da contratação pública de bens, obras e serviços públicos, de acordo com os regimes jurídicos pertinentes. As Administrações Públicas da União, dos Estados federados, dos Municípios e do Distrito federal são compradoras importantes de bens, de contratação direta de obras e serviços e, além disso, concedem, permitem e autorizam a execução de obras e serviços públicos o que resulta num considerável número de contratos públicos, que têm seu fundamento constitucional genérico nos princípios, objetivos e direitos fundamentais e, especificamente, nos artigos 22, XXVII ${ }^{50}, 37, \mathrm{XXI}^{51}, 173, \S 1{ }^{\circ}, \mathrm{III}^{52}$ e $175^{[53]}$ da Constituição federal.

Em matéria de licitação e contratação pública, a União possui competência para dispor sobre normas gerais, densificadas na Lei federal de n. ${ }^{\circ} 8.666$, de 21 de junho de 1993, instituindo normas para licitações e contratos da Administração Pública, além de dispor sobre outras providências que a Administração Pública deve tomar ao contratar. Ao estabelecer as normas gerais sobre licitações e contratos administrativos pertinentes a obras, serviços, inclusive de publicidade, compras, alienações e locações no âmbito dos Poderes da União, dos Estados, do Distrito Federal e dos Municípios, definou as modalidades

"Art. 22. Compete à União: XXVII - normas gerais de licitação e contratação, em todas as modalidades, para as administrações públicas diretas, autárquicas e fundacionais da União, Estados, Distrito Federal e Municípios, obedecido o disposto no art. 37, XXI, e para as empresas públicas e sociedades de economia mista, nos termos do art. $173, \S 1 .^{\circ}$, III".

51 "Art. 37. A administração pública direta e indireta de qualquer dos Poderes da União, dos Estados, do Distrito Federal e dos Municípios obedecerá aos princípios de legalidade, impessoalidade, moralidade, publicidade e eficiência e, também, ao seguinte: XXI - ressalvados os casos especificados na legislação, as obras, serviços, compras e alienações serão contratados mediante processo de licitação pública que assegure igualdade de condições a todos os concorrentes, com cláusulas que estabeleçam obrigações de pagamento, mantidas as condições efetivas da proposta, nos termos da lei, o qual somente permitirá as exigências de qualificação técnica e econômica indispensáveis à garantia do cumprimento das obrigações".

52 "Art. 173. Ressalvados os casos previstos nesta Constituição, a exploração direta de atividade econômica pelo Estado só será permitida quando necessária aos imperativos da segurança nacional ou a relevante interesse coletivo, conforme definidos em lei. $\S 1^{\circ} \mathrm{A}$ lei estabelecerá o estatuto jurídico da empresa pública, da sociedade de economia mista e de suas subsidiárias que explorem atividade econômica de produção ou comercialização de bens ou de prestação de serviços, dispondo sobre: III - licitação e contratação de obras, serviços, compras e alienações, observados os princípios da administração pública". cessão ou permissão, sempre através de licitação, a prestação de serviços públicos". 
de licitação: concorrência, tomada de preços, convite, concurso e leilão. Tem como objetivo garantir a observância do princípio constitucional da isonomia, a seleção da proposta mais vantajosa para a administração e a promoção do desenvolvimento nacional sustentável e será processada e julgada em estrita conformidade com os princípios básicos da legalidade, da impessoalidade, da moralidade, da igualdade, da publicidade, da probidade administrativa, da vinculação ao instrumento convocatório, do julgamento objetivo e dos que lhes são correlatos.

Esta lei define o contrato todo e qualquer ajuste entre órgãos ou entidades da Administração Pública e particulares, em que haja um acordo de vontade para a formação de vínculo e a estipulação de obrigações recíprocas, seja qual a denominação utilizada e regulam-se pelas suas cláusulas e pelos preceitos de direito público, aplicando-se-lhes, supletivamente, os princípios da teoria geral dos contratos e as disposições de direito privado, os quais devem estabelecer com clareza e precisão as condições para sua execução, expressas em cláusulas que definam os direitos, obrigações e responsabilidades das partes, em conformidade com os termos da licitação e da proposta a que se vinculam, além de um conjunto cláusulas necessárias que todo contrato deve contemplar, o que não afasta a possibilidade de regulação de matérias estranhas à lei, mas necessária para atender ao princípio da sustentabilidade contratual.

A competência para definir normas gerais, ainda que o capu do artigo 22 preveja competência privativa da União para legislar sobre normas gerais de licitação e contratação pública, é certo que os Estados, os Municípios e o Distrito federal podem legislar supletivamente sobre matéria licitatória e de contratação pública, visto que a União não pode legislar exclusivamente sobre a matéria e, além disso, aos Estados da Federação são reservadas as competências que não lhes sejam vedadas pela Constituição e, os Municípios, podem suplementar a legislação federal e a estadual no que couber.

Além das modalidades de licitação previstas na Lei federal de n. ${ }^{\circ} 8.666 / 93$, a Lei Federal de n. ${ }^{\circ}$ 10.520, de 17 de julho de 2002, instituiu, no âmbito da União, Estados, Distrito Federal e Municípios, nos termos do art. 37, inciso XXI, da Constituição Federal, modalidade de licitação denominada pregão, para aquisição de bens e serviços comuns, definindo-os como aqueles cujos padrões de desempenho e qualidade possam ser objetivamente definidos pelo edital, por meio de especificações usuais no mercado, além de dispor circunstancialmente sobre a contratação pública, como por exemplo, a autoridade competente, ainda na fase preparatória do edital, deve definir as cláusulas do contrato, inclusive com fixação dos prazos para fornecimento, além de a minuta do contrato integrar o edital.

Outra Lei que disciplina a contratação pública, embora de forma específica, é a de n. ${ }^{\circ}$ 12.462, de 4 de agosto de 2011, que instituiu o Regime Diferenciado de Contratações Públicas - RDC, aplicável exclusivamente às licitações e contratos necessários à realização dos Jogos Olímpicos e Paraolímpicos de 2016; 
da Copa das Confederações da Federação Internacional de Futebol Associação - Fifa 2013 e da Copa do Mundo Fifa 2014, restringindo-se, no caso de obras públicas, às constantes da matriz de responsabilidades celebrada entre a União, Estados, Distrito Federal e Municípios; de obras de infraestrutura e de contratação de serviços para os aeroportos das capitais dos Estados da Federação distantes até $350 \mathrm{~km}$ (trezentos e cinquenta quilômetros) das cidades sedes da Copa do Mundo Fifa 2014.

Posteriormente o Regime Diferenciado de Contratação-RDC passou a ser aplicado, também, às licitações e contratos das ações integrantes do Programa de Aceleração do Crescimento (PAC); às obras e serviços de engenharia no âmbito do Sistema Único de Saúde - sus; às obras e serviços de engenharia para construção, ampliação e reforma e administração de estabelecimentos penais e de unidades de atendimento socioeducativo; às ações no âmbito da segurança pública; das obras e serviços de engenharia, relacionadas a melhorias na mobilidade urbana ou ampliação de infraestrutura logística, para os contratos de locação de bens móveis e imóveis, nos quais o locador realiza prévia aquisição, construção ou reforma substancial, com ou sem aparelhamento de bens, por si mesmo ou por terceiros, do bem especificado pela administração; às ações em órgãos e entidades dedicados à ciência, à tecnologia e à inovação e às licitações e aos contratos necessários à realização de obras e serviços de engenharia no âmbito dos sistemas públicos de ensino e de pesquisa, ciência e tecnologia.

As licitações e contratações por meio do Regime Diferenciado de Contratação-RDC tem por objetivos ampliar a eficiência nas contratações públicas e a competitividade entre os licitantes; promover a troca de experiências e tecnologias em busca da melhor relação entre custos e benefícios para o setor público; incentivar a inovação tecnológica ${ }_{i}$ e assegurar tratamento isonômico entre os licitantes e a seleção da proposta mais vantajosa para a administração pública e deverão observar os princípios da legalidade, da impessoalidade, da moralidade, da igualdade, da publicidade, da eficiência, da probidade administrativa, da economicidade, do desenvolvimento nacional sustentável, da vinculação ao instrumento convocatório e do julgamento objetivo.

Por ser uma lei mais recente do que a Lei Geral de Licitações e Contratações, revela preocupação com a contratação sustentável, ao prever que as contratações realizadas com base no RDC devem respeitar, especialmente, as normas relativas à disposição final ambientalmente adequada dos resíduos sólidos gerados pelas obras contratadas; mitigação por condicionantes e compensação ambiental, que serão definidas no procedimento de licenciamento ambiental, utilização de produtos, equipamentos e serviços que, comprovadamente, reduzam o consumo de energia e recursos naturais; avaliação de impactos de vizinhança, na forma da legislação urbanística, proteção do patrimônio cultural, histórico, arqueológico e imaterial, inclusive por meio da avaliação do impacto direto ou indireto causado pelas obras contratadas e acessibilidade para o uso por pessoas com deficiência ou com mobilidade reduzida. Eventual impacto negativo sobre 
os bens do patrimônio cultural, histórico, arqueológico e imaterial tombados deverá ser compensado por meio de medidas determinadas pela autoridade responsável, na forma da legislação aplicável.

Outra Lei recente que trata de licitação e contratação pública de forma específica é a de n. ${ }^{\circ} 13.303$, de 30 de junho de 2016, que dispõe sobre o estatuto jurídico da empresa pública, da sociedade de economia mista e de suas subsidiárias, no âmbito da União, dos Estados, do Distrito Federal e dos Municípios e, nos capítulos I e II trata dispõe sobre regras aplicáveis às empresas públicas, às sociedades de econonomia mista e às suas subsidiárias que explorem atividade econômica de produção ou comercialização de bens ou de prestação de serviços, ainda que a atividade econômica esteja sujeita ao regime de monopólio da União ou seja de prestação de serviços públicos, em especial a licitação e a contratação de bens, obras e serviços.

O processo de contratação pública, em que figuram no polo ativo as empresas públicas e sociedades de economia mista, é regido por regras e critérios distintos da Lei Geral de Licitações e Contratos da Administração Pública, a despeito da possibilidade de utiulização subsidiária, destina-se a assegurar a seleção da proposta mais vantajosa, inclusive no que se refere ao ciclo de vida do objeto, e a evitar operações em que se caracterize sobrepreço ou superfaturamento, devendo observar os princípios da impessoalidade, da moralidade, da igualdade, da publicidade, da eficiência, da probidade administrativa, da economicidade, do desenvolvimento nacional sustentável, da vinculação ao instrumento convocatório, da obtenção de competitividade e do julgamento objetivo.

Acerca da contratação de concessão e permissão de obras e serviços públicos, existe no Brasil a Lei federal n. ${ }^{\circ}$ 8.987, de 13 de fevereiro de 1995, que dispõe sobre os contratos de concessão e permissão de obras e serviços públicos, no âmbito dos quais o poder concedente delega a prestação do serviço público, mediante licitação, na modalidade de concorrência, à pessoa jurídica ou consórcio de empresas que demonstre capacidade para seu desempenho, por sua conta e risco e por prazo determinado e, quando se tratar de concessão de serviço público precedida da execução de obra pública, o poder concedente, mediante licitação, na modalidade de concorrência, concede à pessoa jurídica ou consórcio de empresas que demonstre capacidade para a sua realização, por sua conta e risco, de forma que o investimento da concessionária seja remunerado e amortizado mediante a exploração do serviço ou da obra por prazo determinado. A permissão de serviço público, por sua vez, se caracteriza pela delegação, a título precário, mediante licitação, da prestação de serviços públicos, feita pelo poder concedente à pessoa física ou jurídica que demonstre capacidade para seu desempenho, por sua conta e risco.

Ainda relacionada com a concessão e permissão de serviços públicos, existe a Lei federal de n. ${ }^{\circ} 9.074$, de 7 de julho de 1995, alterada posteriormente pelas Leis federais de n. ${ }^{\circ} \mathrm{s} 9.648 / 98$ e 13.015/2015, a qual estabelece normas 
para outorga e prorrogações das concessões e permissões de serviços públicos entre outras providências, dispondo que se sujeitam ao regime de concessão ou, quando couber, de permissão, nos termos da Lei n. ${ }^{\circ} 8.987 / 95$, os serviços e obras públicas de competência da União que compreendem as vias federais, precedidas ou não da execução de obra pública, aexploração de obras ou serviços federais de barragens, contenções, eclusas ou outros dispositivos de transposição hidroviária de níveis, diques, irrigações, precedidas ou não da execução de obras públicas e os serviços postais.

Além destas, existe ainda, a Lei federal n. ${ }^{\circ} 11.079$, de 30 de dezembro de 2004, que instituiu normas gerais para licitação e contratação de parceria público-privada no âmbito da dos Poderes da União, dos Estados, do Distrito Federal e dos Municípios, a qual se aplica aos órgãos da administração pública direta dos Poderes Executivo e Legislativo, aos fundos especiais, às autarquias, às fundações públicas, às empresas públicas, às sociedades de economia mista e às demais entidades controladas direta ou indiretamente pela União, Estados, Distrito Federal e Municípios.

Por definição legal a parceria público-privada é o contrato administrativo de concessão, na modalidade patrocinada ou administrativa. A primeira é a concessão de serviços públicos ou de obras públicas de que trata a Lei n. ${ }^{\circ} 8.987 / 95$, quando envolver, adicionalmente à tarifa cobrada dos usuários contraprestação pecuniária do parceiro público ao parceiro privado e a segunda, o contrato de prestação de serviços de que a Administração Pública seja a usuária direta ou indireta, ainda que envolva execução de obra ou fornecimento e instalação de bens, o que exclui a concessão comum, assim entendida a concessão de serviços públicos ou de obras públicas de que trata a Lei n. ${ }^{\circ} 8.987 / 95$, quando não envolver contraprestação pecuniária do parceiro público ao parceiro privado. A Lei veda expressamente a celebração de contrato de parceria público-privada: cujo valor do contrato seja inferior a $\mathrm{R} \$ 20.000 .000,00$ (vinte milhões de reais); cujo período de prestação do serviço seja inferior a 5 (cinco) anos; ou que tenha como objeto único o fornecimento de mão-de-obra, o fornecimento e instalação de equipamentos ou a execução de obra pública.

Sobre o regime jurídico das parcerias público-privadas, esclarece-se que as concessões administratativas são regidas pela Lei federal n. ${ }^{\circ} 11.079 / 2004$, aplicando-se-lhes, adicionalmente, as disposições dos artigos, 23, 25 e 27 a 39 da Lei $n^{\circ} 8.987 / 95$ e o art. 31 da Lei n. ${ }^{\circ} 9.074 / 95$; as concessões patrocinadas regem-se, também, pela Lei, 11.079/2004, mas aplicam-se subsidiariamente as disposições da Lei n. ${ }^{\circ} 8.987 / 95$ e as leis que lhe são correlatas e, por fim, as concessões comuns continuam regidas pela Lei n. ${ }^{\circ} 8.987 / 95$ e pelas leis que the são correlatas, não se lhes aplicando a Lei 11.079/2004. Os contratos administrativos que não caracterizam concessão comum, patrocinada ou administrativa, são regidos exclusivamente pela Lei n. ${ }^{\circ} 8.666 / 93$, e pelas leis que lhe são correlatas os contratos administrativos. 
As diretrizes da contratação de parceria público-privada, de acordo com a Lei federal n. ${ }^{\circ} 11.079 / 2004$, são: a eficiência no cumprimento das missões

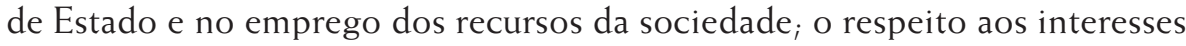
e direitos dos destinatários dos serviços e dos entes privados incumbidos da sua execução; a indelegabilidade das funções de regulação, jurisdicional, do exercício do poder de polícia e de outras atividades exclusivas do Estado; a responsabilidade fiscal na celebração e execução das parcerias; a transparência dos procedimentos e das decisões; a repartição objetiva de riscos entre as partes e a sustentabilidade financeira e vantagens socioeconômicas dos projetos de parceria.

Contudo, em face da ampliação da regulação da atividade econômica, que vai além das leis em sentido formal, tendo em vista que compreende também a regulação feita pelas agências reguladoras ou entes estatais descentralizados, que mesmo não sendo agências reguladoras, exercem funções de regulação, como por exeplo, o Banco Central do Brasil, que faz a regulação do sistema financeiro, com a finalidade de assegurar a estabilidade da moéda, far-se-ão na sequência, considerações sobre a regulação da contratação pública pelas agências reguladores, especialmente sobre os seus limites e as suas possibilidades.

\section{DA REGULAÇÃO DA CONTRATAÇÃO PÚBLICA PELAS AGÊNCIAS REGULADORAS: LIMITES E POSSIBILIDADES}

As agências reguladoras, como já afirmado anteriormente, foram importadas de outro contexto jurídico, econômico e social o que dificulta a sua inserção no ordenamento jurídico pátrio e, por isso, surgiram inúmeros questionamentos destacando-se aqui o chamado poder normativo ${ }^{54}$ das agências reguladoras, porque "essa competência normativa atribuída às agências reguladoras é a chave de uma desejada atuação célere e flexível para a solução, em abstrato e em concreto, de questões em que predomina a escolha técnica" ${ }^{155}$ embora seja difícil extremar de forma absoluta uma decisão técnica de uma decisão política.

54 "A tradição norte-americana conduziu a uma ampliação muito significativa da competência normativa das agências. Adotou-se entendimento que permite ao Legislativo estabelecer um núcleo normativo extremamente reduzido, com ampla autonomia normativa para as agências. Quando se reconhece a existência de competência normativa para as agências reguladoras, não se pretende adotar as concepções norte-americanas. O princípio da legalidade, entre nós, significa a necessidade do ato legislativo disciplinar extensamente a matéria. Os dados fundamentais da hipótese de incidência e do mandamento normativo apenas podem ser veiculados por meio de lei. Não se admite que a lei estabeleça um padrão abstrato, preenchível pelos mais variados conteúdos, e remeta à agência seu desenvolvimento autônomo". MarÇAL Justen FILHO, O direito das agências reguladoras independentes, São Paulo: Dialética, 2002. p. 525.

55 Diogo de Figueiredo Moreira Neto, Mutações do direito administrativo, Rio de Janeiro: Renovar, 2000, p. 162. 
As agências reguladoras no Brasil são entidades autárquicas, criadas por lei específica em obediência ao mandamento constitucional estatuído do artigo 37, XIX, dotadas de independência e poder normativo, características que as diferenciam dos demais entes autárquicos ordinários, "promovendo uma verdadeira revolução copernicana no Direito Administrativo brasileiro: a conferência de poderes normativos a essas entidades, regulando suas áreas de atuação com boa margem de liberdade ${ }^{1156} \mathrm{e}$ que até o presente momento ainda não chegou ao final, a despeito da atuação em concreto das agências reguladoras, embora isto não seja exclusivamente no Brasil, considerando que até mesmo nos Estados Unidos a independência das agências "vem ganhando pesadas críticas" ${ }^{\prime \prime 7}$.

No âmbito da doutrina administrativista brasileira existem várias justificativas para a conferência de poderes normativos às agências reguladoras, tais como: teses funcionalistas, o argumento do espaço reservado ao Executivo, a delegificação ou deslegalização, a competência inerente ao modelo regulatório, a justificativa pela eficiência, o poder regulamentar do Executivo e a discricionariedade administrativa e para todas elas existem argumentos favoráveis e desfavoráveis, especialmente se confrontados com os princípios da separação de poderes e da legalidade ${ }^{58}$, especialmente porque a Constituição brasileira adota o princípio da reserva legal.

A luz dos princípios da separação de poderes - na verdade um mecanismo de repartição das funções desempenhada pelo Estado em órgãos distintos, permitindo-se o controle recíproco ${ }^{59}$ - e da legalidade, que são estruturantes do Estado Democrático de Direito e do exercício da democracia, o poder normativo das agências reguladoras fica bastante limitado: primeiro, porque não existe amparo para que as agências reguladoras tenham independência em face dos Poderes Executivo, Legislativo e Judiciário; segundo, porque as agências reguladoras, por serem autarquias, ainda que com características especiais, não têm poder legiferante, mas apenas a autoadministração ${ }^{60}$.

56 Laís CALIL, "O poder normativo das agências reguladoras em face dos princípios da legalidade e da separação de poderes", in: Agências reguladoras e democracia, GuSTAVo BinENBOjM (Coordenador), Rio de Janeiro: Lúmen Juris, 2006, p. 130.

57 Ibidem, p. 141.

58 O texto de Laís CALIL, "O poder normativo das agências reguladoras em face dos princípios da legalidade e da separação de poderes", in: Agências reguladoras e democracia, Gustavo Binenbojm (Coordenador), Rio de Janeiro: Lúmen Juris, 2006, apresenta os principais argumentos pró e contra para cada uma das justificativas.

59 Ibidem, p. 136.

60 Brasil, Supremo Tribunal Federal. Ação cível originária n. ${ }^{\circ}$ 1.048/RS. Questão de Ordem. Relator Ministro Celso de Mello. Julgado em 30 de agosto de 2007. Publicado no Diário da Justiça em 31 de agosto de 2007. Trecho "O princípio da reserva de lei atua como expressiva limitação constitucional ao poder do Estado, cuja competência regulamentar, por tal razão, não se reveste de suficiente idoneidade jurídica que lhe permita restringir direitos ou criar obrigações. Nenhum ato regulamentar pode criar obrigações ou restringir direitos, sob pena de incidir em domínio constitucionalmente reservado ao âmbito de 
Como visto anteriormente, o Supremo Tribunal Federal-STF, na Adin-MC n. ${ }^{\circ} 1.668-\mathrm{DF}$, se posicionou pela constitucionalidade do poder normativa das agências reguladoras, ao assegurar as funções normativas das agências reguladoras, mas demarcando o exercício nos limites da lei, pois de acordo com trecho do voto do Ministro Sepúlveda Pertence "nada impede que a Agência tenha funções normativas, desde, porém, que absolutamente subordinadas à legislação, e, eventualmente, às normas de segundo grau, de caráter regulamentar, que o Presidente da República entenda baixar. Assim, [...] entendo que nada pode subtrair da responsabilidade do agente político, que é o Chefe do Poder Executivo, a ampla competência reguladora da lei das telecomunicações. Dou interpretação conforme para enfatizar que os incisos IV e X referem-se a normas subordinadas à lei e, se for o caso, aos regulamentos do Poder Executivo".

O campo de atuação das agências reguladoras, no exercício da competência regulatória, deve ficar restrito aos limites estabelecidos pela Constituição e a legislação infraconstitucional, pouco importando se constitucionalmente previstas ou inseridas por força de lei infraconstitucional, porque existem princípios e comandos constitucionais que dispõem sobre a estrutura e organização do Estado, que não podem ser sacrificados em nome de uma das finalidades da Administração Pública que é a regulação, ou seja, as agências reguladoras no Brasil estão submetidas à ordem jurídica positiva estabelecida pelos Poderes Executivo e Legislativo.

Então no exercício da regulação da atividade econômica do Estado, com a finalidade de limitar os graus de liberdade dos agentes econômicos no processo de tomada de decisões, protegendo a concorrência e indução ao desenvolvimento econômico e social, com base em dois critérios que são a eficiência e o aumento do bem-estar social. O aumento do bem-estar social, em parte depende de políticas públicas e estas também, em parte, são concretizadas por meio de contratações públicas, por isso, a atividade de regulação se conecta com a atividade de contratação.

Mas quais são os limites e as possibilidades da regulação da contratação pública pelas agências reguladoras?

É inegável a existência de uma intersecção entre regulação e contrato, visto que o contrato existe tanto na esfera privada, quanto pública, com base na regulação estatal, podendo, contudo, ele mesmo ser considerado como fonte de regulação, ao dispor sobre a conduta, o comportamento dos sujeitos na

atuação material da lei em sentido formal. O abuso de poder regulamentar, especialmente nos casos em que o Estado atua 'contra legem' ou 'praeter legem', não só expõe o ato transgressor ao controle jurisdicional, mas viabiliza, até mesmo, tal a gravidade desse comportamento governamental, o exercício, pelo Congresso Nacional, da competência extraordinária que lhe confere o art. 49, inciso v, da Constituição da República e que lhe permite 'sustar os atos normativos do Poder Executivo que exorbitem o poder regulamentar (...)'. Doutrina. Precedentes" (RE 318.873-AgR/SC, Rel. Min. Celso de Mello). 
relação jurídica contratual. A despeito desta afirmação inicial e geral, é certo que as conexões e intersecções entre a regulação e a contratação pode variar de acordo com a natureza do contrato: privado ou público. Tratando-se de contratação privada, a regulação administrativa tem por finalidade proibir, restringir e limitar as liberdades contratuais, sem afastar a possibilidade de imposição de obrigações de fazer.

A tarefa da regulação dos contratos cabe predominantemente ao legislador, mas não exclusivamente, porque certas intervenções de regulação são feitas por autoridades da Administração Pública direta, em especial o Chefe do Poder Executivo, com base no poder regulamentar que a Constituição federal lhe atribui, sem prejuízo da regulação por outras autoridades administrativas, como por exemplo, Ministros e Secretários de Estado, no exercício da competência regulatória secundária. Esclarece-se, que o exercício regulamentar pelas autoridades administrativas, em linhas gerais, decorre da prerrogativa conferida à Administração Pública para editar atos gerais para complementar as leis e possibilitar sua efetiva aplicação.

Além da regulação feita por autoridades do Poder Executivo, existem outras possibilidades de regulação, como por exemplo: a) intervenções contratuais feitas com base em atos e medidas promovidas no âmbito da regulação administrativa da economia, por autoridades de regulação, sempre no âmbito da demarcação estabelecida pelo legislador ${ }^{61}$; b) medidas administrativas relacionadas a contratos envolvendo relações de consumo, como ocorre com os Procon's integrantes do Sistema Nacional de Defesa do Consumidor - SNDC $;$ C) a regulação por força de contrato de programa, conforme estabelecido na lei que disciplina o regime jurídico dos consórcios públicos ${ }^{62} ;$ d) regulação de contratos por entes

61 Brasil, Decreto n. ${ }^{\circ} 6.523$, de 31 de julho de 2008 - Regulamenta a Lei n. ${ }^{\circ} 8.078$, de 11 de setembro de 1990, para fixar normas gerais sobre o Serviço de Atendimento ao Consumidor - SAC. O PRESIDENTE DA REPÚBLICA, no uso da atribuição que lhe confere o art. 84, inciso IV, da Constituição, e tendo em vista o disposto na Lei n. ${ }^{\circ} 8.078$, de 11 de setembro de 1990, DECRETA: Art. 1. ${ }^{\circ}$ Este Decreto regulamenta a Lei n. ${ }^{\circ} 8.078$, de 11 de setembro de 1990, e fixa normas gerais sobre o Serviço de Atendimento ao Consumidor - SAC por telefone, no âmbito dos fornecedores de serviços regulados pelo Poder Público federal, com vistas à observância dos direitos básicos do consumidor de obter informação adequada e clara sobre os serviços que contratar e de manter-se protegido contra práticas abusivas ou ilegais impostas no fornecimento desses serviços. Disponível em: http://www.procon. pr.gov.br/arquivos/File/decreto_6523_08_sac.pdf [Acesso em: 27 de julho de 2017].

62 Brasil, Lei federal n. ${ }^{\circ} 11.107$, de 6 de abril de 2005 - Dispõe sobre normas gerais de contratação de consórcios públicos e dá outras providências. Art. 13. Deverão ser constituídas e reguladas por contrato de programa, como condição de sua validade, as obrigações que um ente da Federação constituir para com outro ente da Federação ou para com consórcio público no âmbito de gestão associada em que haja a prestação de serviços públicos ou a transferência total ou parcial de encargos, serviços, pessoal ou de bens necessários à continuidade dos serviços transferidos. $\S 10^{\circ} \mathrm{O}$ contrato de programa deverá: I - atender à legislação de concessões e permissões de serviços públicos e, especialmente no que se 
administrativos descentralizados que não possuem status de agência reguladora, como é o caso do Banco Central do Brasil, como por exemplo os contratos de câmbio ${ }^{63}$ e e, e) a regulação de contratos pelas agências reguladoras.

Enquanto que no contrato particular a regulação é parcial, no contrato pública a regulação é total, porque o contrato público é uma instituição publicamente regulada, porque submetida a uma regulação específica de direito público administrativo, o que não afasta, no plano concreto a regulação da relação contratual pelo próprio contrato, mas de acordo com as regras decorrentes da regulação pública. Contudo, a questão é saber se as agências reguladoras têm prerrogativas para exercer a regulação de contratações públicas e quais os limites e as possibilidades.

Como ponto de partida é necessário deixar demarcado que as agências reguladoras têm as suas atribuições definidas por lei, visto que não possuem competência legislativa, nem independência em face dos Poderes Executivo, Legislativo e Judiciário, como já foi visto anteriormente, o que impõe a elas exercer a regulação nos limites estabelecidos pela Constituição e pela legislação infraconstitucional. Então, se por força de atribuição constitucional ou legal, as agências têm a atribuição de exercer a regulação sobre a contratação pública, isto deve ser de acordo com a ordem jurídica, o que permite afirmar que a competência legislativa para a contratação pública é do Poder Legislativo, afastando de plano a inovação da ordem jurídica via função regulatória executada pelas agências reguladoras.

A título de exemplo, a Lei Federal de n. ${ }^{\circ} 9.472$, de 16 de julho de 1997, que instituiu a Agência Nacional de Telecomunicações-ANATEL, prevê que compete à União, por intermédio do órgão regulador e nos termos das políticas estabelecidas pelos Poderes Executivo e Legislativo, organizar a exploração dos serviços de telecomunicações. A organização inclui, entre outros aspectos, o disciplinamento e a fiscalização da execução, comercialização e uso dos serviços

refere ao cálculo de tarifas e de outros preços públicos, à de regulação dos serviços a serem prestados" (grifado). Disponível em: http://www.planalto.gov.br/ccivil_03/_ato2004-2006/2005/ lei/111107.htm [Acesso em 27 de julho de 2017].

63 Brasil, Circular n. ${ }^{\circ} 3.691$, de 16 de dezembro de 2013. Regulamenta a Resolução n. ${ }^{\circ} 3.568$ de 29 de maio de 2008, que dispõe sobre o mercado de câmbio e dá outras providências. Art. 40. Contrato de câmbio é o instrumento específico firmado entre o vendedor e o comprador de moeda estrangeira, no qual são estabelecidas as características e as condições sob as quais se realiza a operação de câmbio. Art. 41. As operações de câmbio são formalizadas por meio de contrato de câmbio, conforme o modelo do Anexo I a esta Circular, e seus dados devem ser registrados no Sistema Câmbio, consoante o disposto no capítulo II deste título, devendo a data de registro do contrato de câmbio no Sistema Câmbio corresponder ao dia da celebração de referido contrato. Parágrafo único. As características de impressão do contrato de câmbio podem ser adaptadas pela instituição autorizada, sem necessidade de prévia anuência do Banco Central do Brasil, observada a integridade das informações requeridas. Disponível em: http://www.bcb.gov.br/Rex/LegCE/Port/Circular3691.asp?idpai=CAMBIOREGULA [Acesso em 28 de julho de 2017]. 
e da implantação e funcionamento de redes de telecomunicações, bem como da utilização dos recursos de órbita e espectro de radiofreqüencias. E, para tanto, o Poder Público tem o dever de adotar medidas que promovam a competição e a diversidade dos serviços, incrementem sua oferta e propiciem padrões de qualidade compatíveis com a exigência dos usuários, entre outras atribuições.

Estas medidas que promovem a competição e a diversidade dos serviços, com a finalidade de incremetar a oferta, propiciando padrões de qualidade compatíveis com a exigência dos usuários, certamente possuem conexão e intersecção com os contratos de concessão ou permissão para a exploração de serviços de telecomunicações e de uso de radiofreqüência e, também, nos vículos jurídicos que se estabelecem entre a concessionário ou permissionária e os usuários dos serviços públicos concedidos ou permitidos, mas sempre nos limites estabelecidos pela legislação, o que afasta a possibilidade de inovar a ordem jurídica.

Outro exemplo de regulação de agência reguladora com atribuições que se conectam e interseccionam na regulação de contratos de concessão e permissão do serviço de energia elétrica, além de repercutir na relação contratual entre as concessionárias e permissionárias e os usuários dos serviços é a Agência $\mathrm{Na}$ cional de Energia Elétrica-ANEEL, instituída por força da Lei federal n. ${ }^{\circ} 9.427$, de 26 de dezembro de 1996, na condição de autarquia sob regime especial, vinculada ao Ministério de Minas e Energia, com sede e foro no Distrito Federal e prazo de duração indeterminado tendo por finalidade regular e fiscalizar a produção, transmissão, distribuição e comercialização de energia elétrica, em conformidade com as políticas e diretrizes do governo federal.

Além das competências previstas na Lei Geral de concessões e permissões, incumbe a ela, entre outras, implementar as políticas e diretrizes do governo federal para a exploração da energia elétrica e o aproveitamento dos potenciais hidráulicos, expedindo os atos regulamentares necessários ao cumprimento das normas estabelecidas pela Lei n. ${ }^{\circ} 9.074$, de 7 de julho de 1995 ; promover, mediante delegação, com base no plano de outorgas e diretrizes aprovadas pelo Poder Concedente, os procedimentos licitatórios para a contratação de concessionárias e permissionárias de serviço público para produção, transmissão e distribuição de energia elétrica e para a outorga de concessão para aproveitamento de potenciais hidráulicos.

Deve gerir os contratos de concessão ou de permissão de serviços públicos de energia elétrica, de concessão de uso de bem público, bem como fiscalizar, diretamente ou mediante convênios com órgãos estaduais, as concessões, as permissões e a prestação dos serviços de energia elétrica, estabelecer tarifas para o suprimento de energia elétrica realizado às concessionárias e às permissionárias de distribuição, tarifas de fornecimento às cooperativas autorizadas, considerando parâmetros técnicos, econômicos, operacionais e a estrutura dos mercados atendidos; estabelecer metas a serem periodicamente alcançadas, visando a universalização do uso da energia elétrica. 
A ANEEL quando propiciar concorrência entre os agentes com a finalidade de impedir a concentração econômica nos serviços e atividades de energia elétrica e quiser impor restrições, limites ou condições para empresas, grupos empresariais e acionistas, para a obtenção e transferência de concessões, permissões e autorizações, para a concentração societária e para a realização de negócios entre si, zelar pelo cumprimento da legislação de defesa da concorrência, monitorando e acompanhando as práticas de mercado dos agentes do setor de energia elétrica, deverá articular-se com a Secretaria de Direito Econômico do Ministério da Justiça, o que demonstra que a independência da agência reguladora é nos limites da lei.

A despeito de não ter sido feito uma pesquisa exaustiva acerca do tratamento específico da regulação da contratação pública pelas agências reguladoras, no exercício de suas atribuições, talvez seja possível afirmar que o tema - regulação da contratação pública pelas agências reguladoras - vem sendo tratado apenas de forma oblíqua, no contexto das discussões acerca da legitimidade democrática e do poder normativo em face dos princípios da separação de poderes e da legalidade, porque não foram encontradas obras específicas na doutrina administrativas brasileira.

Da mesma forma o tema da regulação dos contratos administrativos pelas agências reguladoras apresenta escassa jurisprudência ${ }^{64}$, na medida em que são normalmente consumidores os sujeitos que levam ao Judiciário demandas que envolvem a relação entre o particular destinatário do serviço e o particular prestador. Logo, percebe-se nos julgados que não há um olbar específico para o papel das agências reguladoras no contrato administrativo, ou seja, para os efeitos das normativas das agências reguladoras na relação entre o poder concedente e o concedido.

Todavia, não há como negar que a jurisprudência atinge esse tema de forma reflexa ao discorrer sobre os contornos que as concessionárias possuem para agir no campo econômico. Nesse sentido, os contratos administrativos são abordados, por exemplo, em relação ao poder de revisão tarifária que lhes é inerente, que é fruto tanto da lei quanto das espécies normativas das agências reguladoras. É nesse diapasão que se encontra o Recurso Especial n. ${ }^{\circ}$ 976.836/ RS, cujo acórdão de repetitivo versou sobre a possibilidade de repasse do PIS e da COFINS nas tarifas de serviços de telefonia, não versando diretamente sobre a regulação de contratos administrativos pela ANATEL.

$\mathrm{Na}$ referida demanda, a agência ingressou nos autos na qualidade de amicus curiae, defendendo a possibilidade do repasse, conforme se aduz do seguinte

64 Local de busca: sítio eletrônico do STF.

a) Foi digitado no campo de busca os seguintes termos: agência adj reguladora e contrato adj administrativo e como resultado, foram encontrados 2 acórdãos (ADI 1923/DF, sobre o dever de licitação das Organizações Sociais e Ag.Rg. no RE com agravo n. ${ }^{\circ} 766.799$ ), 9 decisões monocráticas, 1 decisão da presidência e 2 informativos. 
trecho colacionado pelo relator: "Com os argumentos assim ordenados e apoio na legislação supracitada, inexiste fundamento jurídico para a inconformidade da recorrente, pois cabível a transferência do ônus financeiro do PIS e da COFINS, bem como de tributos diretos, para o preço final da tarifa telefônica cobrada do contribuinte, por integrarem os custos na composição final do preço" (Voto do Relator, Ministro Luiz Fux, p. 21).

Com efeito, a partir desse julgado, fixou-se que, pelo fato de o serviço de telefonia configurar um serviço público prestado mediante concessão, remunerado, assim, mediante tarifa, é inviável tratar do repasse de tributos por meio de outros instrumentos senão o edital da licitação, o contrato de concessão, as normas reguladoras da ANATEL e o disposto no Código de Defesa do Consumidor (p. 28). Da mesma forma, encontrou-se entendimento semelhante no AgRg nos EDcl no Conflito de Competência n. ${ }^{\circ} 61847 / \mathrm{CE}$, quando, através da colação de precedentes, assentou-se o aval dado pela ANATEL às concessionárias para a cobrança de "assinatura básica mensal", a título de manutenção do serviço de telefonia (ainda que a decisão tenha sido, em sua essência, sobre a competência para julgamento diante de possível litisconsórcio entre a concessionária e a ANATEL).

Portanto, percebe-se que, ao tratar de um contrato privado (a relação entre o consumidor e uma concessionária), o Poder Judiciário abordou de forma perfunctória as normas (tanto oriundas do Poder Legislativo quanto das agências) que incidem no contrato administrativo de concessão que confere poderes à empresa privada. No REsp 572070/PR, por exemplo, sustentou-se a importância da regulamentação da ANATEL para fins de execução dos contratos entre concessionária e particulares. Com isso, sustentou-se também a intervenção atenuada do Poder Judiciário nessas regras (quando se mostrarem compatíveis com o ordenamento), de forma a evitar uma desestabilização na prestação dos serviços. Ao cabo, tal posicionamento demonstrou que os contratos de concessão deverão se mostrar dependentes dos conceitos regulamentados pela agência do setor referente $e^{65}$.

Veja-se, nesse sentido, trecho destacado do mencionado recurso especial: "Há de se ter em mente que a regulamentação do setor de telecomunicações, nos termos da Lei n. 9.472/97 e demais disposições correlatas, visa a favorecer o aprimoramento dos serviços de telefonia em prol do conjunto da população brasileira. Esse objetivo, entretanto, somente será atingido com uma política regulatória estável que privilegie a ação das Agências Reguladoras, pautada em regras claras e objetivas, sem o que não se cria um ambiente favorável ao desenvolvimento do setor, sobretudo em face da notória e reconhecida incapacidade do Estado em arcar com os eventuais custos inerentes ao processo" (Voto do Relator, Ministro João Otávio de Noronha, p. 6).

65 No julgado em comento, discutiu-se no mérito a definição de "área local" dada pela agência reguladora para fins de estabelecimento de tarifas. 
Assim sendo, reconhece-se na jurisprudência uma possibilidade de regulação dos contratos administrativos pelas agências reguladoras através do seu poder normativo, o qual condiciona os termos de execução do serviço público delegado. Tal situação fica clara na análise do agravo interno no mandado de segurança n. ${ }^{\circ}$ 22583/DF, o qual versou sobre impugnação à mudança da sede fiscal de dada usina hidrelétrica. No acórdão, o relator evidencia que a partir da Lei n. ${ }^{\circ} 12.783 / 13$, as concessões de energia serão licitadas na modalidade leilão ou concorrência, cujos procedimentos ficarão a cargo da ANEEL. Assim, aduz que "sendo a formalização do contrato de concessão precedida de licitação, é do instrumento convocatório o papel de se definir os critérios e as normas gerais a serem aplicadas na contratação, que, no caso in comento, abrangeria as características e as localizações das Usinas concedidas" (Voto do Relator, Ministro Mauro Campbell Marques, p. 6).

Nesta senda, as eventuais nulidades presentes no contrato administrativo de concessão seriam também relacionadas a disposições da licitação coordenada pela agência reguladora. Conforme assevera o relator, "assim, possível nulidade, capaz de comprometer a lisura de toda contratação, reportar-se-ia ao edital de licitação, haja vista ter o contrato de concessão o dever de ater às regras nele elencadas" (p. 6).

Interessante também perceber a conferência de poder às agências reguladoras para fiscalizar os contratos administrativos, fato que também se observou por via reflexa, através do Ag.Rg. no RE com agravo n. ${ }^{\circ} 766.799$ do STF. Nesse julgado, o STF pugnou pela inocorrência de violação direta à Constituição no recurso, afastando, por consequência, o julgamento de mérito da causa. Entretanto, ao fazê-lo, trouxe também dados que mostraram a ocorrência de aplicação de sanção à uma concessionária por parte da agência reguladora (AGENERSA) pelo descumprimento das medidas impostas por suas diretrizes, as quais incidem diretamente nos deveres postos no contrato administrativo.

Nesse sentido, a título de complementação, lembra-se que o TCu controla a atuação das agências reguladoras no controle dos contratos de concessão, mas a fiscalização destes, por sua vez, é de responsabilidade das agências reguladoras. Nesta senda, em acórdão proferido pelo tribunal de contas, o mesmo assentou o seguinte: "Não compete ao TCu fiscalizar diretamente as empresas delegatárias de serviço público, mas sim examinar se o poder concedente está fiscalizando de forma adequada a execução dos contratos celebrados, por força do disposto nos arts. 70 e 71 da Constituição Federal de 1988. No caso das operadoras de serviços de telecomunicações, essa atribuição cabe à Agência Nacional de Telecomunicações, nos termos do art. 19 da Lei 9.472/1997"66.

66 Acórdão 1089/2016 - Plenário. Processo: 008.336/2015-6. Disponível em: http://portal. tcu.gov.br/data/files/24/B6/3F/63/F01A45105E5D87451A2818A8/008.336-2015-6\%20 -\%20SCN\%20Qualidade\%20TV\%20assinatura\%20e\%20banda\%20larga.pdf [Acesso em: 22 jul. de 2017]. 
Por derradeiro, conclui-se que a jurisprudência se mostra incipiente sob o ponto de vista quantitativo no que se refere ao tema da regulação dos contratos administrativos por parte das agências reguladoras. Tal fato se atribui à preponderância de questionamentos por parte de membros da sociedade civil em relação às concessionárias, não havendo demandas identificadas destas em relação ao poder concedente, as quais possibilitariam a análise direta das regulamentações das agências nos contratos administrativos.

\section{CONCLUSÕES}

O Estado brasileiro, a despeito das obrigações impostas pela Constituição de 1988, não conseguiu garantir a concretização dos direitos fundamentais, especialmente os de natureza social em face da crise fiscal que assolou os países, notadamente periféricos econômica e socialmente, o que serviu de justificativa para aderir a lógica da globalização econômica o que impactou as relações entre o público e o privado e contribuiu para uma nova formatação do Estado e, por consequência, da Administração Pública.

Esta nova forma de relacionamento entre o Estado e a Sociedade se deu por força da reforma do Estado, o qual deixou de intervir diretamente na prestação dos serviços públicos e na atividade econômica de produção e comercialização de bens, passando a atuar predominantemente por meio da regulação setorial da economia, diretamente ou indiretamente por entidades autárquicas, parte delas chamadas de agências reguladoras.

Uma das questões tormentosas envolvendo as agências reguladoras é o seu déficit democrático, visto que as decisões que elas tomam, a despeito de serem predominantemente técnicas, inegavelmente acabam fazendo escolhas políticas e os seus agentes diretivos não são escolhidos pelo povo. Existem argumentos entendendo que elas não apresentam déficit democrático, desde que instituídas de acordo com os comandos constitucionais e, além disso, há a possibilidade de participação popular na tomada de decisões. Contudo, a simples faculdade de participar sem ter condições de influir na tomada de decisão, talvez não supere o chamado déficit democrático.

Outra dificuldade relacionada com as agências reguladoras é a legitimidade do seu poder normativo, especialmente se confrontado com os princípios da separação de poderes e a legalidade. Não existe consenso na doutrina administrativista brasileira acerca do tema, o que é revelado pelas múltiplas justificativas apresentadas e as contraposições demonstrando a fragilidade das justificativas. Contudo, a Supremo Tribunal federal-STF entende que as agências reguladoras podem exercer a função de regulação, desde que de acordo com os parâmetros legais.

Nesta senda vem a questão principal do trabalho que é sobre os limites e as possibilidades de regulação da contratação pública por meio das agências reguladoras. A despeito de a pesquisa não ser exaustiva, o tema não tem sido 
tratado pontualmente pela doutrina, nem pela jurisprudência das Cortes superiores, em especial o Superior Tribunal de Justiça-STJ e pelo Supremo Tribunal Federal-STF. Contudo, conclui-se que as agências podem exercer a regulação sobre a contratação pública, porque exercem parcela da atividade de regulação, todavia deve ser nos limites da Constituição e da legislação infraconstitucional, porque embora sejam qualificadas como independentes, não possuem independência em face dos Poderes Executivo, Legislativo e Judiciário.

O princípio da separação de poderes, na perspectiva da separação de funções e o princípio da legalidade são estruturantes da organização e funcionalidade do Estado, e com base neles estão definidas as competências e atribuições de cada um dos Poderes. As entidades que integram a Administração Pública indireta, ficam circunscritas à autoadministração, o que impede elas de inovar a ordem jurídica, de sorte que a regulação sobre a contratação pública é de acordo com os parâmetros estabelecidos pelo Legislador que está legitimado democraticamente.

\section{BIBLIOGRAFÍA}

Aragão, Alexandre Santos De. Agências reguladoras: e a evolução do direito administrativo econômico, 3. ${ }^{\text {a }}$ edição revista e ampliada, Rio de Janeiro: Forense, 2013.

Aranha, Marcio. Manual de Direito Regulatório (Locais do Kindle 329-334), Laccademia Publishing, Edição do Kindle.

Binenbojm, Gustavo. "Agências reguladoras independentes e Democracia no Brasil", In: Agências Reguladoras e Democracia, Gustavo Binenbojm (Coordenador), Rio de Janeiro: Lúmen Juris, 2006.

Bonavides, Paulo. Do Estado Liberal ao Estado Social, 10ª ed., São Paulo: Malheiros, 2001.

Calil, Laís. "O poder normativo das agências reguladoras em face dos princípios da legalidade e da separação de poderes", in: Agências reguladoras e democracia, Gustavo Binenbojm (Coordenador), Rio de Janeiro: Lúmen Juris, 2006.

Chevallier, Jacques. O Estado Pós-Moderno. Tradução de Marçal Justen Filho. Belo Horizonte: Fórum, 2009.

Grau, Eros Roberto. O direito posto e o direito pressuposto, 9. a edição revista e ampliada, São Paulo: Malheiros, 2014.

Justen Filho, Marçal. O direito das agências reguladoras independentes, São Paulo: Dialética, 2002

Justen Filho, MarçAl. "Agências reguladoras e democracia: existe um déficit democrático na "regulação independente?", In: O poder normativo das agências reguladoras, 
Alexandre Santos de Aragão (Coordenador) ... [et al]. Rio de Janeiro: Forense, 2006.

Justen Filho, Marçal. Curso de Direito Administrativo, 4. ed. rev. atual., São Paulo: Saraiva, 2009.

Leal, Rogério Gesta. Estado, administração pública e sociedade: novos paradigmas. Porto Alegre: Livraria do Advogado, 2006

Marques Neto, Floriano Peixoto De Azevedo. "Nova regulação dos serviços públicos", Revista de Direito Administrativo, Rio de Janeiro, v. 228, pp. 13-30, abr. 2002. ISSN 2238-5177. Disponível em: http://bibliotecadigital.fgv.br/ojs/index.php/rda/ article/view/46521 [Acesso em: 27 Jul. 2017]. doi:http://dx.doi.org/10.12660/rda. v228.2002.46521.

Mattos, Paulo Todescan Lessa. Regulação econômica e democracia: contexto e perspectivas na compreensão das agências de regulação no Brasil, In: Regulação, Direito e Democracia, (Organizador) José Eduardo Faria, São Paulo: Editora Fundação Perseu Abramo, 2002.

Mello, Celso Antônio Bandeira De. Curso de direito administrativo, 19. ${ }^{a}$ ed, Malheiros: São Paulo, 2005.

Mendes, Conrado Hübner. "Reforma do Estado e Agências Reguladoras: estabelecendo parâmetros para discussão", in: Direito Administrativo Econômico, CARlos ARI Sundfeld (Coordenador), São Paulo: Malheiros, 2000.

Moreira Neto, Diogo de Figueiredo. Mutações do direito administrativo, Rio de Janeiro: Renovar, 2000.

Pereira, Luiz Carlos Bresser. "Da administração pública burocrática à gerencial", In: Reforma do estado e administração pública gerencial, (Organizadores) LuIz CARLOS Bresser Pereira e Peter Kevin Spink, tradução Carolina Andrade,. 7. a ed., Rio de Janeiro: Editora FGV, 2005.

Silva, Ilse GOMES. A reforma do Estado A reforma do Estado brasileiro nos anos 90: brasileiro nos anos 90: processos e contradições. Dispinível em: http://www4.pucsp.br/neils/downloads/ v7_ilse_gomes.pdf [Acesso em 26 de julho de 2017].

Streck, Lenio Luiz e Morais, José Luís Bolzan de. Ciência política e teoria do estado, 7. ed. Porto Alegre: Livraria do Advogado, 2012. 